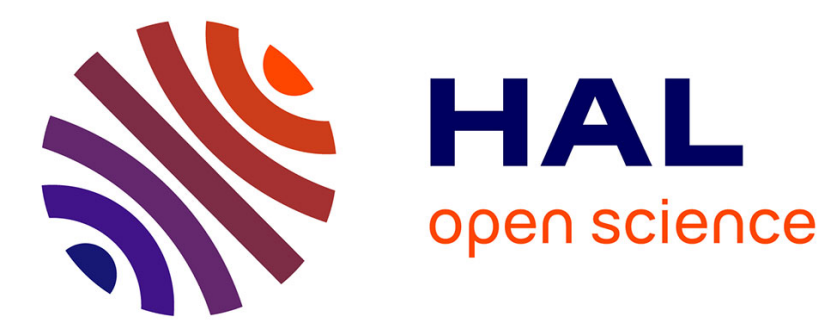

\title{
Persistent organic pollutants and stable isotopes in pinnipeds from King George Island, Antarctica
}

Caio V. Z. Cipro, Paco Bustamante, Satie Taniguchi, Rosalinda Carmela

Montone

\section{- To cite this version:}

Caio V. Z. Cipro, Paco Bustamante, Satie Taniguchi, Rosalinda Carmela Montone. Persistent organic pollutants and stable isotopes in pinnipeds from King George Island, Antarctica. Chemosphere, 2011, 85 (3), pp.393-398. 10.1016/j.chemosphere.2011.07.047 . hal-00819442

\section{HAL Id: hal-00819442 \\ https://hal.science/hal-00819442}

Submitted on 1 May 2013

HAL is a multi-disciplinary open access archive for the deposit and dissemination of scientific research documents, whether they are published or not. The documents may come from teaching and research institutions in France or abroad, or from public or private research centers.
L'archive ouverte pluridisciplinaire HAL, est destinée au dépôt et à la diffusion de documents scientifiques de niveau recherche, publiés ou non, émanant des établissements d'enseignement et de recherche français ou étrangers, des laboratoires publics ou privés. 
Persistent organic pollutants and stable isotopes in pinnipeds from King George Island, Antarctica

Caio V. Z. Cipro ${ }^{*}, 1,2$, Paco Bustamante ${ }^{2}$, Satie Taniguchi ${ }^{1}$ \& Rosalinda Carmela Montone ${ }^{1}$

'Universidade de São Paulo, Instituto Oceanográfico, Praça do Oceanográfico, 191, 05508-120 São Paulo-SP, Brasil

${ }^{2}$ Littoral Environnement et Sociétés (LIENSs), UMR 7266, CNRS-Université de La Rochelle, 2 rue Olympe de Gouges 17042 La Rochelle Cedex 01, France

*Corresponding author: caiovzc@gmail.com 


\section{Highlights:}

- PCBs, DDTs and Chlordanes are the prevailing organochlorines in Antarctic seals

- Results showed a clear stratification in accordance to ecological data

- Stable isotopes analysis provides a deeper insight on data fluctuations

Abstract: In the present work, fat, skin, liver and muscle samples from Leptonychotes weddellii (Weddell seal, $\mathrm{n}=2$ individuals), Lobodon carcinophagus (crabeater seal, $\mathrm{n}=2$ ), Arctocephalus gazella (Antarctic fur seal, $\mathrm{n}=3$ ) and Mirounga leonina (southern elephant seal, $n=1$ ) were collected from King George Island, Antarctica, and analysed for POPs (PCBs, organochlorine pesticides and PBDEs) and stable isotopes $\left(\delta^{13} \mathrm{C}\right.$ and $\delta^{15} \mathrm{~N}$ in all tissues but fat). PBDEs could be found in only one sample ( $L$. weddellii fat). Generally, PCBs (from 74 to $523 \mathrm{ng} \mathrm{g}^{-1} \mathrm{Iw}$ ), DDTs (from 14 to $168 \mathrm{ng} \mathrm{g}^{-1} \mathrm{lw}$ ) and chlordanes (from 9 to $78 \mathrm{ng} \mathrm{g}^{-1} \mathrm{Iw}$ ) were the prevailing compounds. Results showed a clear stratification in accordance with ecological data. Nonetheless, stable isotope analyses provide a deeper insight into fluctuations due to migrations and nutritional stress. Correlation between $\square^{15} \mathrm{~N}$ and pollutants suggests, to some degree, a considerable ability to metabolize and/or excrete the majority of them.

Keywords: Antarctica; Seal; Stable isotopes; Organochlorine; PBDEs; POPs 


\section{Introduction}

Antarctica, in spite of being the most isolated continent on Earth, has not escaped the deleterious effects of human activity. Its unique marine ecosystems and their endemic faunas are affected on local and regional scales by overharvesting, pollution and the introduction of alien species (Aronson et al., 2011). Persistent Organic Pollutants (POPs) are deposited in Antarctica following the process of global distillation, and the cold conditions of the Antarctic environment favour their persistence compared to temperate and tropical environments (de Wit et al., 2006). The storage of lipids as an energy source makes Antarctic food webs vulnerable to bioaccumulative chemicals, and top predators are the species exposed to the greatest risk (Loganathan et al., 1990; Loganathan and Kannan, 1991).

Pinnipeds and other marine mammals differ from terrestrial ones because their high rates of lactational energy transfer to the young, primarily because of the elevated milk lipid content (Carlini et al., 2000). This characteristic also contributes to the transfer of lipophilic contaminants to the young. In cetaceans and pinnipeds, more than $90 \%$ of organochlorine contaminants present in neonates are transferred through milk, greatly exceeding gestational transfer before birth (Addison and Stobo, 1993; Borrell et al., 1995). Because of their elevated trophic position in the marine environment, their relatively long life spans and their elevated energy requirements, pinnipeds can also be regarded as sentinel species for studying contaminant bioaccumulation and its deleterious effects (Ross, 2000).

Limited information is available for both POP levels and isotopic ratios for Antarctic pinnipeds. In this context, the aim of the present work is to evaluate 
the occurrence and transfer of organic contaminants (organochlorine compounds and polybrominated diphenyl ethers) in Antarctic pinnipeds using stable isotope analysis (SIA) as an ecological tool to provide a deeper understanding of the results, since carbon and nitrogen supply data, respectively, on carbon sources exploited by consumers and trophic position (Lesage et al., 2002). $\delta^{13} \mathrm{C}$ values are generally used as a tracer of the habitat or the feeding zone of organisms (France, 1995; Hobson, 1999). $\delta^{15} \mathrm{~N}$ values are particularly used as an indicator of the trophic position (TP) of organisms, and have been widely employed to calculate the absolute or relative trophic level of organisms in various ecosystems by measuring their concentrations in tissues of a suite of consumers, since they are enriched in $\delta^{15} \mathrm{~N}$ relative to their food (Hobson and Welch, 1992; Lesage et al., 2001). Conversely, $\delta^{13} \mathrm{C}$ values vary little ( $1 \%$ per trophic level versus 3 to $5 \%$ from $\delta^{15} \mathrm{~N}$ ) along the food chain and are mainly used to determine sources of primary production in a trophic network (DeNiro and Epstein, 1978). In the marine environment, $\delta^{13} \mathrm{C}$ values can also indicate inshore vs offshore, or pelagic vs benthic, contribution to food intake (France, 1995). Furthermore, the knowledge of the food chain length is one key aspect for understanding the transfer of organic contaminants in marine food webs. Overall, SIA and derived TP and/or feeding zones of organisms may thus help to investigate the transfer of POPs in food webs of interest (Dietz et al., 2004). 


\section{Material and methods}

\subsection{Sampling}

Samples were collected from King George Island $\left(62^{\circ} 05^{\prime} \mathrm{S} 58^{\circ} 23 \mathrm{~W}\right)$ in the austral summers of $2004 / 05$ and $2005 / 06$. Sampling was fully opportunistic, i.e. only from animals found already dead, with no signs of degradation. All samples were taken using previously n-hexane-rinsed instruments, stored in previously combusted ( $420 \stackrel{\circ}{\mathrm{C}}$ for $4 \mathrm{~h}$ ) aluminium containers and kept at $-20 \stackrel{\circ}{\mathrm{C}}$ until analysis (last analysis concluded in early 2010). Leptonychotes weddellii (Weddell seal, $\mathrm{n}=2$ individuals: fat, skin, liver and muscle), Lobodon carcinophagus (crabeater seal, $\mathrm{n}=2$ individuals: fat, skin and muscle), Arctocephalus gazella (Antarctic fur seal, $\mathrm{n}=3$ individuals: fat, skin, liver and muscle) and Mirounga leonina (southern elephant seal, $\mathrm{n}=1$ individual: liver and muscle) are the species that were sampled for the present study.

\subsection{Chemical analyses}

Organochlorine $(\mathrm{OC})$ and PBDE analyses were performed at the University of São Paulo (Brazil). Laboratory protocol was based on MacLeod et al. (1986) and quality assurance/quality control (QA/QC) followed guidelines described by Wade and Cantillo (1994). Extraction and clean-up were common for all contaminant analyses. Briefly, wet samples $(0.25 \mathrm{~g}$ for fat, $2.5 \mathrm{~g}$ for liver $)$ were ground with anhydrous $\mathrm{Na}_{2} \mathrm{SO}_{4}$ and surrogate (PCB 103) was added before extraction in a Soxhlet apparatus for $8 \mathrm{~h}$ with $80 \mathrm{~mL}$ of $\mathrm{n}$-hexane and methylene chloride $(1: 1, \mathrm{v} / \mathrm{v})$. The extract was concentrated (by 
rotoevaporation) to $1 \mathrm{~mL}$ and cleaned up in a column filled (from top to bottom) with $16 \mathrm{~g}$ alumina and $8 \mathrm{~g}$ silica gel (both $5 \%$ deactivated with water). The extract was eluted (100 mL of methylene chloride) and subsequently concentrated (also by rotoevaporation) to $500 \mu \mathrm{L}$. A further clean-up step was performed in an HPLC-size exclusion column system: two Phenogel $100 \mathrm{~A}$ $(22.5 \times 250 \mathrm{~mm})$ and a $7.8 \times 50 \mathrm{~mm}$ precolumns. Methylene chloride was used as mobile phase. A new rotoevaporation (up to $900 \mu \mathrm{L}$ ) followed, and finally, internal standard (100 $\mu \mathrm{L}$ TCMX, used to estimate surrogate recovery) was added to the purified extract prior to injection in the gas chromatograph.

$\mathrm{OC}$ analyses were run in a gas chromatograph equipped with an electron capture detector (GC-ECD, Agilent Technologies, model 6890N). Hydrogen was used as carrier gas at constant pressure (13.2 psi, i.e. 91.01 $\mathrm{kPa})$. The injector was operated in splitless mode and kept at $300^{\circ} \mathrm{C}$. The capillary column used was a DB-5 (30 m length $\times 250 \mu \mathrm{m}$ internal diameter $\times$ $0.25 \mu \mathrm{m}$ film thickness). The detector operated at $320{ }^{\circ} \mathrm{C}$ using $\mathrm{N}_{2}$ as makeup gas at a flow rate of $58 \mathrm{~mL} \mathrm{~min}{ }^{-1}$. The oven was programmed as follows: $70{ }^{\circ} \mathrm{C}$ for $1 \mathrm{~min}, 5{ }^{\circ} \mathrm{C} \cdot \mathrm{min}^{-1}$ to $140{ }^{\circ} \mathrm{C}(1 \mathrm{~min}), 1.5{ }^{\circ} \mathrm{C} \cdot \mathrm{min}^{-1}$ to $250{ }^{\circ} \mathrm{C}(1 \mathrm{~min})$ and 10 ${ }^{\circ} \mathrm{C} \cdot \mathrm{min}^{-1}$ to $300{ }^{\circ} \mathrm{C}$ (5 min). The investigated compounds were PCBs (IUPAC Nos. $8,18,28,31,33,44,49,52,56,60,66,70,74,77,87,95,97,99,101$, $105,110,114,118,123,126,128,132,138,141,149,151,153,156,157,158$ 167, 169, 170, 174, 177, 180, 183, 187, 189, 194, 195, 199, 201, 203, 206 and 209), DDTs (o,p'-DDE, p,p'-DDE, o, p'-DDD, $p, p^{\prime}-\mathrm{DDD}, o, p^{\prime}-D D T$, and $\left.p, p^{\prime}-\mathrm{DDT}\right)$, $\mathrm{HCB}, \mathrm{HCHs}(\alpha, \beta, \gamma$, and $\delta$ isomers), chlordanes ( $\alpha$ - and $\gamma$-chlordane, heptachlor and heptachlor epoxide), mirex and drins (aldrin, dieldrin and endrin). Surrogate recovery ranged from $98 \%$ to $111 \%$. Detection limits were set as three times the 
standard deviation $(\sigma)$ of seven method blank replicates. Spiked matrices were recovered within the acceptance ranges (i.e. $40-130 \%$ for at least $80 \%$ of the spiked analytes) suggested by Wade and Cantillo (1994). Method validation was performed using NIST SRM 1945 (Organics in Whale Blubber). Blanks were included in every analytical batch (usually 10-12 samples) and all data were blank-subtracted.

PBDE analyses were performed in a gas chromatograph 6890 Plus attached to the MS 5973N mass detector, with an HP-5MS column (30 m long $\mathrm{x}$ $250 \mu \mathrm{m}$ internal diameter and internal film $0.25 \mu \mathrm{m}$ thick). The congeners analysed were the IUPAC \# 28, 47, 99, 100, 153, 154 and 183. The injector operated at $270^{\circ} \mathrm{C}$. The oven was programmed as follows: $130 \stackrel{\circ}{\mathrm{C}}$ for $1 \mathrm{~min}, 12$ ${ }^{\circ} \mathrm{C} \min ^{-1}$ until $154 \stackrel{\circ}{\circ} \mathrm{C}(0 \mathrm{~min}), 2{ }^{\circ} \mathrm{C} \mathrm{min}^{-1}$ until $210 \stackrel{\circ}{\circ}$ (0 min), $3{ }^{\circ} \mathrm{C} \mathrm{min}^{-1}$ until 300 ${ }^{\circ} \mathrm{C}$ (5 min). PCB 103 was used as surrogate and TCMX as internal standard.

Stable isotope analyses (SIA) were performed at the University of La Rochelle (France). Prior to SIA, samples were lyophilized and ground to obtain a fine powder. One aliquot of $100 \mathrm{mg}$ of sample was placed in a test tube with 4 $\mathrm{mL}$ of cyclohexane to remove lipids. The mixture was shaken for an hour, then centrifuged for separation (as many times as needed, until the liquid phase, which is discarded, comes out clear) and dried at $50{ }^{\circ} \mathrm{C}$ for $48 \mathrm{~h}$. Purified samples were analysed using a Thermo Scientific Delta V Advantage, ConFlo IV interface (NoBlank and SmartEA) and Thermo Scientific Flash EA1112 Elemental Analyzer. Each injection corresponded to $0.4 \pm 0.1 \mathrm{mg}$ of sample encapsulated in tin cups, and there were no replicates. Pee Dee Belemnite and atmospheric nitrogen were used as standards for calculation of $\delta^{13} \mathrm{C}$ and $\delta^{15} \mathrm{~N}$, respectively. Based on replicate measurements of internal laboratory standards, 
experimental precision is of \pm 0.15 and $\pm 0.20 \%$ for $\delta^{13} \mathrm{C}$ and $\delta^{15} \mathrm{~N}$, respectively.

Statistical tests were performed in Microsoft Excel (2007 version) and StatSoft Statistica (10.0) at $\mathrm{P}=0.05$ and non-parametric distribution.

\section{Results and discussion}

\subsection{Organic pollutants}

With regard to PBDE analyses, only one sample (fat from L. weddellii) presented concentration superior to the MDLs, which was $2.04 \mathrm{ng} \mathrm{g}^{-1}$ Iw (lipid weight), only for BDE \#99. This congener is the second most present in the technical formula available in the Americas, with a profile reasonably similar to the Antarctic environmental results as in Yogui and Sericano (2008). However, another study (Corsolini et al., 2007) points out some interspecific differences that could be interpreted as being the result of the fractionation of the technical product. In fat samples from A. gazella pups, Schiavone et al. (2009b) reported an equally small concentration of PBDEs of $2.35 \mathrm{ng} \mathrm{g}^{-1} \mathrm{ww}$. An important fact that might explain these apparently low values is the small distance from the base of the food web that some of these organisms occupy, due to the representativeness of euphausiids in their diets. This is specially the case for Lobodon carcinophagus, which feed on krill, Euphausia superba, practically all year round (Berta et al., 2006). Such a specialized diet also appears for $A$. gazella when it forages in Antarctic waters (Berta et al., op. cit.). For comparison purposes, the closest trophic equivalent to $L$. weddellii in the northern hemisphere would be the grey seal, Halichoerus grypus, with the closest (yet slightly higher) $\delta^{15} \mathrm{~N}$ (data from Aubail et al., 2011). Since no 
significant difference in $\delta^{15} \mathrm{~N}$ values is found for primary producers in either hemisphere (Horton et al., 2009; Mincks et al., 2008), the difference between $H$. grypus and L. weddellii (around 0.8\%o) must be taken into account. Ikonomou and Addison (2008) report averages for PBDEs in grey seals ranging from 27.8 up to $319 \mathrm{ng} \mathrm{g}^{-1}$ Iw depending on the remoteness of the collection site. Nevertheless, this represents from one up to two orders of magnitude above the levels found in the single sample from the present work which overcame the MDLs. Higher values in the northern hemisphere can be explained by greater contamination as a result of the presence of industrialized countries in a greater extent. These outputs have been highlighted for POPs in general but also for other contaminants such as petroleum hydrocarbons (Poland et al., 2003). Another reason might be that food chains in the Arctic are somewhat longer than in the Antarctic (Aubail et al., 2011).

The results obtained for organochlorine compounds are shown in Table 1. As previously stated, L. carcinophagus allegedly has the lowest trophic level among the analysed species (Table 1). This fact can directly explain why this species displays the lowest $\mathrm{OC}$ and PBDE concentrations. There is a clear stratification found between the species, in spite of different ecological niches, which will be further discussed in the stable isotope analysis section. As a basis for comparison, Yogui (2002) found DDTs, PCBs, mirex, chlordanes and HCB concentrations in L. weddellii from the same area of the present study in the same order of magnitude (i.e. $460 \mathrm{ng} \mathrm{g}^{-1}, 150 \mathrm{ng} \mathrm{g}^{-1}, 18 \mathrm{ng} \mathrm{g}^{-1}, 4 \mathrm{ng} \mathrm{g}^{-1}$ and 2 $\mathrm{ng} \mathrm{g}^{-1}$ in lipid weight, respectively). However, Yogui (op. cit.) shows an inversion of the $\Sigma \mathrm{DDT} / \Sigma \mathrm{PCB}$ ratio, indicating a decrease in the inputs from agricultural 
activity in relation to industrial ones during the last decade.

Quantitative data for A. gazella are in the same order of magnitude as previously reported in fat (Schiavone et al., 2009ab), as well as for M. leonina in liver samples (juveniles reported in Miranda-Filho et al., 2007). Kajiwara et al. (2001) presented data in the same order of magnitude, in a general way, for fat and liver in pinnipeds (the California sea lion, Zalophus californianus, the northern elephant seal, Mirounga angustirostris and the harbour seal, Phoca vitulina) from California. When compared to $M$. leonina from the present study, OCs show slightly lower concentrations in M. angustirostris (Kajiwara et al., 2001). One must take into account that, even though collections by Kajiwara et al. (op. cit.) were made in the boreal summer, such an environment is not as seasonal as the Antarctic and therefore fluctuations due to nutritional stress should be lower.

L. weddellii show higher values (from one to two orders of magnitude) when compared to the ones found for one population in the same area of study by Vetter et al. (2003). However, when comparing our values to those for the population from Terra Nova Bay, which is located south (at $74^{\circ} \mathrm{S}$ ) and therefore more subject to the effect of cold trap (Vetter et al., op. cit.) both data sets are compatible. This might be better explained by the possible nutritional stress of the individuals collected for the present work. Indeed, such a stress would notably remobilize and increase the concentrations of contaminants in the tissues (Burek et al., 2008).

The qualitative profile of PCBs is shown in Figure 1. With regard to PCB distribution, A. gazella presents the proportionally heavier profiles, followed by L. weddellii and then by L. carcinophagus, in an analogous arrangement to the 
one found in Table 1. Because of the greater environmental persistence of the heavier congeners (Fuoco \& Ceccarini, 2001), the biomagnification effect not only makes absolute values higher throughout a trophic web, but also makes qualitative profiles heavier. Previous data for $A$. gazella (Schiavone et al., 2009ab) show a reasonably similar distribution, with the exception of octa-CBs, which prevailed then and represented less than $5 \%$ of the total PCBs in the present study.

In the liver, M. leonina showed a similar congener distribution to the one presented by Miranda-Filho et al. (2007), in which prevailed the hexa (51.2\%), penta (17.8\%) and hepta-CBs (15.9\%); hexa-CBs also prevailed in the present work, however less significantly (32.8\%), followed by hepta and tetra-CBs (Figure 1).

\subsection{Stable isotopes}

Opportunistic sampling limits the number of individuals but at the same time offers the possibility of collecting several different tissues per individual. This presents a great advantage since different tissues have different turnover rates and their stable isotope values therefore represent different integration times.

Stable isotope data are presented in Figure 2. Turnover of stable isotopes varies according to the protein metabolic rate, so the analyses of multiple tissues from one individual allow a more thorough approach by providing data over a range of timescales (Kurle and Worthy, 2002; MèndezFernandez et al., 2012). For nitrogen, according to the literature, liver has the fastest turnover rate, followed by skin and then muscle (Kurle \& Worthy, 2001, 
2002; Lesage et al., 2002). For example, the protein matter half-lives for several tissues of the northern fur seal, Callorhinus ursinus, goes from 1.9 to 6.7 days for the liver and from 12.5 to 83.3 days for the muscle (Kurle \& Worthy, 2002). In the skin of the same species, this variable has been estimated as between 6.4 and 27.6 days (Kurle \& Worthy, 2001). In both of the previous studies, the authors stated that the turnover rate itself ranges from 2 to 3 times the half-life, thus it is possible to deduce, with some approximation, that liver, skin and muscle will reflect the diet from 4 to 20,13 to 83 and 25 to 250 days, respectively, before sampling. This overlapping between liver and skin (13 to 20 days), and especially between skin and muscle (25 to 83 days), is a complicating factor, since the latter might include winter periods, when diet and distribution are less known than during the summer.

Zhao et al. (2004) reported isotopic data for the blood serum of four Antarctic seal species, two of which occur also in the present study ( $L$. carcinophagus and $L$. weddellii). Since this matrix represents a period of the same amplitude as the liver (Lesage et al., 2002), it is reasonable to use them as equivalents for comparison. Results for $\delta^{15} \mathrm{~N}$ show the highest values for $L$. weddellii, followed by $A$. gazella and then by M. leonina. According to dietary studies (Jefferson et al., 2008 and references therein), the importance of benthonic prey is higher for M. leonina than for L. weddellii, whilst for A. gazella the diet is highly seasonal and population dependent. It is worth mentioning that, similarly to what happens with organic pollutant concentrations, $\delta^{15} \mathrm{~N}$ values also increase in individuals under nutritional stress (Lesage et al, 2002; Dehn et al., 2006), which might enlighten the understanding of the obtained results. 
Data for A. gazella show a clear shift in the feeding area due to the large variation in $\delta^{13} \mathrm{C}$ (from -21.6 to -25.0 ; Figure 2), presenting enriched values in skin tissue, the one with the intermediate turnover rate. This suggests a foraging area of lower latitude to be more likely and the increase of coastal/benthic prey in diet to be less likely, which would be reflected in $\delta^{15} \mathrm{~N}$ as well, as shown by Dunton (2001). The results presented for liver, with faster turnover, are plausible with the site collection, whereas the results for muscle, with slower turnover, are plausible with the distribution presented by Jefferson et al. (2008) that reported males in winter even south of the consolidated pack ice. These authors reported the species to occur in some areas north of the Antarctic Convergence, which has a significant effect on $\delta^{13} \mathrm{C}$ (the colder the temperature, the higher the fractionation, e.g. Cherel and Hobson, 2007). With regard to the $\delta^{15} \mathrm{~N}$ fluctuation, Ciaputa and Sicinski (2006) reported variations in the diet of $A$. gazella with the decrease of krill consumption according to its distribution in certain years, but also because fur seals feed closer to the shore at the time of the year they remain in the King George Island area. Consequently, A. gazella increase its fish consumption, which explains the higher $\delta^{15} \mathrm{~N}$ in the tissue with the fastest turnover. In fur seals from Bouvet Island, which is also under the influence of the Antarctic Convergence, more variation in preying on benthonic organisms than pelagic ones has been reported (Jacob et al., 2006), which also enlightens the data set, since in the study area Dunton (2001) reported an average $\delta^{15} \mathrm{~N}$ of $0.5 \%$ for a pelagic primary producer and $4 \%$ for a benthonic one. Thus one might conclude that generally, benthic organisms will have a higher $\delta^{15} \mathrm{~N}$, which will be reflected in their consumers. 
For $L$. weddellii, there seems to be no variation in feeding areas according to the results for $\delta^{13} \mathrm{C}$ analysis in the three tissues as little variation is observed (Fig. 2). Interestingly, temporal variation for this species has been shown at Mawson $\left(68^{\circ} 00^{\prime} \mathrm{S} 066^{\circ} 00^{\prime} \mathrm{E}\right)$, with prey from upper trophic levels being less frequent during winter, as well as the total quantity of prey (Lake et al., 2003). These observations strongly support the fact that a nutritional stress is reflected by the increase in $\delta^{15} \mathrm{~N}$ observed in skin samples. Taking all this information into account, muscle tissue has the lowest $\delta^{15} \mathrm{~N}$ and the slowest turnover rate on average, which would indicate a period of consumption of lower trophic level prey and/or no nutritional stress. This is followed by a period of higher trophic level prey and/or nutritional stress (indicated by skin $\delta^{15} \mathrm{~N}$ values, with the intermediate turnover rate), finally followed by another period of consumption of lower trophic level prey and/or no nutritional stress, indicated by $\delta^{15} \mathrm{~N}$ values of the liver, the tissue with the fastest turnover rate and therefore the one which reflects diet closer to the time of collection. However, this hypothesis is impaired by the overlapping of the tissues' turnover rates, as previously discussed.

With regard to $L$. carcinophagus, the hypothesis of individuals having been collected under nutritional stress is evident for two reasons: firstly, because of the concentrations of organic pollutants, which were in several cases comparable to those from $L$. weddellii, while this species occupies an upper trophic position and is therefore more prone to biomagnification; secondly, because the values of $\delta^{15} \mathrm{~N}$ in the present work are from 3 to $4 \%$ higher than those found by Zhao et al. (2004). Since this species is highly adapted to the consumption of krill, which is largely the most frequent item in its 
diet (Berta et al., 2006), the possibility of a dietary shift capable of justifying such an increase is highly unlikely.

The interpretation of the elephant seal $M$. leonina results presents yet another complicating factor: a significant sexual segregation in diet and feeding strategies and consequently in isotopic analyses, as demonstrated by Lewis et al. (2006). Nevertheless, there seems to be no significant difference for $\delta^{15} \mathrm{~N}$ between the tissues (liver and muscle), which makes the hypothesis of nutritional stress unlikely. This is additionally confirmed by the extractable organic matter content of the liver ( 85\%), which might indicate a good health condition.

\subsection{Statistical tests}

The results for Spearman's rank correlation for the whole data set are shown in Table 2. Only three values were statistically significant, for two reasons: the reduced sampling number and the large fluctuations in data, due to the nutritional stress of some individuals as previously addressed. Correlation with $\delta^{15} \mathrm{~N}$ was negative for all the contaminants, except for endosulphan, DDTs and mirex. This could be due to the fact that 1) these three contaminants are less subject to metabolization/excretion than the others, and/or 2) nutritional stress causes fluctuations proportionally higher in $\delta^{15} \mathrm{~N}$ than in the concentrations of organic pollutants. This second hypothesis is less likely to occur because of the preferential mobilization of lipids compared to proteins. 


\section{Conclusions}

The data presented here, in spite of the limitations caused by small sampling numbers, characteristic of opportunistic sampling studies in remote environments, contribute to the scarce literature on POPs (especially on PBDEs) and SIA, and moreover in the correlation of the two data sets. Results showed stratification in concentrations of organic pollutants in accordance with ecological data, however stable isotope analyses provide a deeper insight into data fluctuations due to migrations, diet change and mainly nutritional stress, made evident by the different turnover rates of the three tissues present in the study, which reflects diet from more than 8 months to a couple of days before the collection. Correlation between $\delta^{15} \mathrm{~N}$ and organic pollutants for the majority of the compounds, especially (but not only) the lighter ones, suggests a considerable ability to metabolize or excrete the compounds. Additionally, important information is given about wintering periods, when several ecological parameters of the species are poorly known.

Acknowledgements: This paper is part of the projects "Environmental Management at Admiralty Bay, King George Island, Antarctica: Persistent organic pollutants and sewage" (process number: 55.0348/2002-6) and "Modelling the fate of organic pollutants through Antarctic trophic web" (process number: 550018/2007-7) funded by the Brazilian Antarctic Program (PROANTAR), sponsored by Ministry of the Environment (MMA) and Conselho Nacional de Desenvolvimento Científico e Tecnológico (CNPq) with logistical support from the "Secretaria da Comissão Interministerial para os Recursos do Mar" (SECIRM). This work contributes to the Brazilian "National Science and 
Technology Institute on Antarctic Environmental Research" (INCT-APA, acronym in Portuguese). Authors wish to thank G. Guillou and P. Richard for technical support during the stable isotope analyses. Part of the analyses were supported financially by LIENSs and the CPER (Contrat de Projet Etat-Région). The authors also thank the Ferraz Station staff, the "eternal" colleagues Dênis da Silva, Sílvio Sasaki and Maurício Coimbra and fellow researchers for their support during the sampling programs from the austral summers of 2004/05 and 2005/06. We would also like to wish best luck in the efforts to reconstruct the Brazilian Antarctic Station and register our deepest sorrow for the decease of Carlos Alberto Vieira Figueiredo and Roberto Lopes dos Santos in the tragic fire from February $25^{\text {th }} 2012$.

\section{References}

Addison, R.F., Stobo, W.T., 1993. Organochlorine residue concentrations and burdens in grey seals (Halichoerus grypus) blubber during the first year of life. Journal of Zoology, London 230, 443-450.

Aronson, R.B., Thatje, S., McClintock, J.B., Hughes, K. A., 2011. Anthropogenic impacts on marine ecosystems in Antarctica. Annals of the New York Academy of Sciences 1223, 82-107.

Aubail, A., Teilmann, J., Dietz, R., Rigét, F., Harkonen, T., Karlsson, O., RosingAsvid, A., Caurant, F., 2011. Investigation of mercury concentrations in fur of phocid seals using stable isotopes as tracers of trophic levels and geographical regions. Polar Biology 34 (9), 1411-1420.

Berta, A., Sumich, J.L., Kovacs, K.M., 2006. 12 - Diet, Foraging Structures and Strategies, in: Marine Mammals. Academic Press, pp. 312-362.

Borrell, A., Bloch, D., Desportes, G., 1995. Age trends and reproductive transfer of organochlorine compounds in long-finned pilot whales from the Faroe Islands. Environmental Pollution 88, 283-292.

Burek, K., Gulland, F., O'Hara, T.M., 2008. Effects of climate change on Arctic marine mammal health. Ecological Applications 18, 126-134. 
Carlini, A.R., Panarello, H.O., Marquez, M.E.I., Daneri, G.A., Soave, G.E., 2000. Energy gain and loss during lactation and postweaning in southern elephant seal pups (Mirounga leonina) at King George Island. Polar Biology 23, 437-440.

Cherel, Y., Hobson, K.A., Guinet, C., Vanpe, C., 2007. Stable isotopes document seasonal changes in trophic niches and winter foraging individual specialization in diving predators from the Southern Ocean. Journal of Animal Ecology 76, 826-36.

Ciaputa, P., Sicinski, J., 2006. Seasonal and annual changes in Antarctic fur seal (Arctocephalus gazella) diet in the area of Admiralty Bay, King George Island, South Shetland Islands. Polish Polar Research 27, 171-184.

Corsolini, S., Berghesi, N., Schiamone, A., Focardi, S., 2007. Polybrominated Diphenyl Ethers, Polychlorinated Dibenzo-dioxins, -furans and -biphenyls in three species of Antarctic penguins. Environmental Science and Pollution Research 14 (6), 421-429.

DeNiro, M., Epstein, S., 1978. Influence of diet on the distribution of carbon isotopes in animals. Geochimica et Cosmochimica Acta 42, 495-506.

de Wit, C. a, Alaee, M., Muir, D.C.G., 2006. Levels and trends of brominated flame retardants in the Arctic. Chemosphere 64, 209-33.

Dehn, L.-A., Follmann, E.H., Thomas, D.L., Sheffield, G.G., Rosa, C., Duffy, L.K., O'Hara, T.M., 2006. Trophic relationships in an Arctic food web and implications for trace metal transfer. The Science of the Total Environment 362, 103-23.

Dietz, R., Riget, F., Hobson, K. a, Heide-Jørgensen, M.P., Møller, P., Cleemann, M., de Boer, J., Glasius, M., 2004. Regional and inter annual patterns of heavy metals, organochlorines and stable isotopes in narwhals (Monodon monoceros) from West Greenland. The Science of the Total Environment 331, 83-105.

Dunton, K.H., 2001. 15N and 13C Measurements of Antarctic Peninsula Fauna: Trophic Relationships and Assimilation of Benthic Seaweeds. Integrative and Comparative Biology 41, 99-112.

France, R.L., 1995. Carbon-13 enrichment in benthic compared to planktonic algae: food web implications. Marine Ecology Progress Series 124, 307312.

Fuoco, R., Ceccarini, A., 2001. Polychlorobiphenyls in Antarctic matrices. Environmental contamination in Antarctica: a challenge for analytical chemistry $169,237-274$

Hobson, K.A., 1999. Tracing origins and migration of wildlife using stable isotopes: a review. Oecologia 120, 314-326. 
Hobson, K.A., Welch, H.E., 1992. Determination of trophic relationships within a high Arctic marine food web using $\delta 13 \mathrm{C}$ and $\delta 15 \mathrm{~N}$ analysis. Marine Ecology Progress Series 84, 9-18.

Horton TW, Blum JD, Xie Z, Hren M, Chamberlain CP (2009) Stable isotope food-web analysis and mercury biomagnification in polar bears (Ursus maritimus). Polar Res 28, 443-454

Ikonomou, M. G.; Addison, R. F., 2008. Polybrominated diphenyl ethers (PBDEs) in seal populations from eastern and western Canada: An assessment of the processes and factors controlling PBDE distribution in seals. Marine Environmental Research 66 (2), 225-230.

Jacob, U., Brey, T., Fetzer, I., Kaehler, S., Mintenbeck, K., Dunton, K., Beyer, K., Struck, U., Pakhomov, E.A, Arntz, W.E., 2006. Towards the trophic structure of the Bouvet Island marine ecosystem. Polar Biology 29, 106113.

Jefferson, T.A., Webber, M.A., Pitman, R.L., 2008. Marine mammals of the world: a comprehensive guide to their identification, in: Marine Mammals of the World: A Comprehensive Guide to Their Identification. Academic Press, London, pp. 306-444.

Kajiwara, N., Kannan, K., Muraoka, M., Watanabe, M., Takahashi, S., Gulland, F., Olsen, H., Blankenship, a L., Jones, P.D., Tanabe, S., Giesy, J.P., 2001. Organochlorine pesticides, polychlorinated biphenyls, and butyltin compounds in blubber and livers of stranded California sea lions, elephant seals, and harbor seals from coastal California, USA. Archives of Environmental Contamination and Toxicology 41, 90-9.

Kurle, C.M., Worthy, G. a J., 2001. Stable isotope assessment of temporal and geographic differences in feeding ecology of northern fur seals (Callorhinus ursinus) and their prey. Oecologia 126, 254-265.

Kurle, C.M., Worthy, G.A.J., 2002. Stable nitrogen and carbon isotope ratios in multiple tissues of the northern fur seal Callorhinus ursinus : implications for dietary and migratory reconstructions. Marine Ecology Progress Series 236, 289-300.

Lake, S., Burton, H., van den Hoff, J., 2003. Regional, temporal and fine-scale spatial variation in Weddell seal diet at four coastal locations in east Antarctica. Marine Ecology Progress Series 254, 293-305.

Lesage, V., Hammill, M.O., Kovacs, K.M., 2002. Diet-tissue fractionation of stable carbon and nitrogen isotopes in phocid seals. Marine Mammal Science 18, 182-193.

Lesage, V., O'Hammill, M., Kovacs, K.M., 2001. Marine mammals and the community structure of the Estuary and Gulf of St Lawrence, Canada: 
evidence from stable isotope analysis. Marine Ecology Progress Series 210, 203- 221.

Lewis, R., O'Connell, T.C., Lewis, M., Campagna, C., Hoelzel, a R., 2006. Sexspecific foraging strategies and resource partitioning in the southern elephant seal (Mirounga leonina). Proceedings. Biological sciences. The Royal Society 273, 2901-7.

Loganathan, B.G., Kannan, K., 1991. Times perspectives of organochlorine contamination in the global environment. Marine Pollution Bulletin. 22, 582584.

Loganathan, B.G., Tanabe, S., Tanaka, H., Miyazaki, N., Amano, M., Tatsukawa, R., 1990. Comparision of persistent organochlorine residues in striped dolphin Stenella coeruleoalba from western North Pacific in 19781986. Marine Pollution Bulletin 21, 435-439.

MacLeod, W.D., Brown, D.W., Friedman, A.J., Burrows, D.G., Maynes, O., Pearce, R.W., Wigren, C.A., Bogar, R.G., 1986. Standard Analytical Procedures of the NOAA National Analytical Facility, 1985-1986. Extractable Toxic Organic Components, second ed. US Department of Commerce, NOAA/NMFS. NOAA Tech. Memo. NMFS F/NWC, pp. 92-121.

Mèndez-Fernandez P., Bustamante P., Bode A., Chouvelon T., Ferreira M., López A., Pierce G. J., Santos M. B., Spitz J., Vingada J.V., Caurant F. (2012) Trophic ecology of five toothed whale species inhabiting the waters of the Northwest of the Iberian Peninsula using $\delta 13 \mathrm{C}$ and $\delta 15 \mathrm{~N}$ isotopic signatures. Journal of Experimental Marine Biology and Ecology, 413(4): 150-158.

Mincks SL, Smith CR, Jeffreys RM, Sumida PYG (2008) Trophic structure on the West Antarctic Peninsula shelf: Detritivory and benthic inertia revealed by $\delta^{13} \mathrm{C}$ and $\delta^{15} \mathrm{~N}$ analysis. Deep-Sea Res Pt II 55, 2502-2514

Miranda-Filho, K.C., Metcalfe, T.L., Metcalfe, C.D., Robaldo, R.B., Muelbert, M.M.C., Colares, E.P., Martinez, P.E., Bianchini, A., 2007. Residues of persistent organochlorine contaminants in southern elephant seals (Mirounga leonina) from Elephant Island, Antarctica. Environmental science and Technology 41, 3829-35.

Poland, J.S., Riddle, M.J., Zeeb, B.A., 2003. Contaminants in the Arctic and the Antarctic: a comparison of sources, impacts, and remediation options. Polar Record 39 (211), 369-383.

Ross, P. S., 2000. Marine Mammals as Sentinels in Ecological Risk Assessment. Human and Ecological Risk Assessment: An International Journal 6(1), 29-46. 
Schiavone, A., Corsolini, S., Borghesi, N., Focardi, S., 2009a. Contamination profiles of selected PCB congeners, chlorinated pesticides, PCDD/Fs in Antarctic fur seal pups and penguin eggs. Chemosphere 76, 264-9.

Schiavone, A., Kannan, K., Horii, Y., Focardi, S., Corsolini, S., 2009b. Occurrence of brominated flame retardants, polycyclic musks, and chlorinated naphthalenes in seal blubber from Antarctica: comparison to organochlorines. Marine Pollution Bulletin 58, 1415-9.

Vetter, W., Weichbrodt, M., Stoll, E., 2003. Indication of Geographic Variations of Organochlorine Concentrations in the Blubber of Antarctic Weddell Seals (Leptonychotes Weddelli). Environmental Science and Technology 37, 840844.

Wade, T.L., Cantillo, A.Y., 1994. Use of Standards and Reference Materials in the Measurement of Chlorinated Hydrocarbon Residues. Chemistry Workbook. NOOA Technical Memorandum NOS ORCA 77. Silver Spring, Maryland.

Yogui, G.T., 2002. Ocorrência de compostos organoclorados (pesticidas e PCBs) em mamíferos marinhos da costa de São Paulo (Brasil) e da llha Rei George (Antártica). MSc dissertation. Instituto Oceanográfico da Universidade de São Paulo.

Yogui, G.T., Sericano, J.L., 2008. Polybrominated diphenyl ether flame retardants in lichens and mosses from King George Island, maritime Antarctica. Chemosphere 73, 1589-93.

Zhao, L., Castellini, M. a, Mau, T.L., Trumble, S.J., 2004. Trophic interactions of Antarctic seals as determined by stable isotope signatures. Polar Biology 27, 368-373. 
Table 1 - Concentrations (in $\mathrm{ng} \mathrm{g}^{-1} \mathrm{Iw}$ ) of organochlorine compounds in fat from the Antarctic fur seal Arctocephalus gazella, the Weddel seal Leptonychotes weddelli, the crabeater seal Lobodon carcinophagus and in liver from the Southern Elephant seal Mirounga leonina from King George Island.

\begin{tabular}{|c|c|c|c|c|c|}
\hline & $\begin{array}{l}\text { Lobodon carcinophagus } \\
\qquad \mathrm{n}=2\end{array}$ & $\begin{array}{l}\text { Arctocephalus gazella } \\
\qquad \mathrm{n}=3\end{array}$ & $\begin{array}{l}\text { Leptonychotes weddelli } \\
\qquad \mathrm{n}=2\end{array}$ & $\begin{array}{l}\text { Leptonychotes weddelli } \\
\text { n=1 from Yogui (2002) }\end{array}$ & $\begin{array}{c}\text { Mirounga leonina } \\
\mathrm{n}=1\end{array}$ \\
\hline$\Sigma \mathrm{HCHs} \quad(\alpha, \beta, \gamma \mathrm{e} \delta)$ & 0.223 & 3.21 & 2.59 & - & 1.41 \\
\hline $\mathrm{HCB}$ & 7.23 & 4.72 & 5.77 & 2 & 7.48 \\
\hline$\Sigma$ Drins (Aldrin, Endrin, Dieldrin and Isodrin) & 18.4 & 82.4 & 18.5 & - & 6.88 \\
\hline $\begin{array}{c}\Sigma \text { Chlordanes (Heptachlor, epoxides, } \\
\text { oxichlordane, } \alpha \text { and } \gamma \text {-Clordano) }\end{array}$ & 22.8 & 78.2 & 9.5 & 4 & 37.7 \\
\hline Endossulfan (I/II) & 2.09 & 21.15 & 14.0 & - & 2.72 \\
\hline $\begin{array}{c}\Sigma \text { DDTs (DDD, DDT and DDE in op' and pp' } \\
\text { configurations) }\end{array}$ & 14.4 & 168 & 131 & 460 & 98.7 \\
\hline Mirex & 14.4 & 17.0 & 5.53 & 18 & 16.2 \\
\hline$\Sigma$ PCBs & 154 & 523 & 300 & 150 & 73.9 \\
\hline
\end{tabular}


Table 2 - Spearman correlation matrix for the whole dataset of the present work. Significative results at $p<0.05$ are bold and marked with an asterisk.

\begin{tabular}{|c|c|c|c|c|c|c|c|c|c|c|}
\hline & $\Sigma \mathrm{HCHs}$ & $\mathrm{HCB}$ & $\Sigma$ Drins & $\Sigma$ Chlordanes & Endossulfan & $\Sigma$ DDTs & Mirex & $\Sigma \mathrm{PCBs}$ & $\Sigma$ PBDEs & $\delta^{15} \mathrm{~N}$ \\
\hline$\Sigma \mathrm{HCHs}$ & 1.00 & & & & & & & & & \\
\hline $\mathrm{HCB}$ & -0.29 & 1.00 & & & & & & & & \\
\hline$\Sigma$ Drins & 0.26 & -0.17 & 1.00 & & & & & & & \\
\hline$\Sigma$ Chlordanes & 0.17 & 0.31 & 0.62 & 1.00 & & & & & & \\
\hline Endossulfan & 0.36 & -0.33 & $0,81^{*}$ & 0.43 & 1.00 & & & & & \\
\hline$\Sigma$ DDTs & 0.43 & -0.33 & 0.52 & 0.24 & $0,88^{*}$ & 1.00 & & & & \\
\hline Mirex & -0.36 & 0.12 & -0.24 & 0.14 & 0.05 & -0.05 & 1.00 & & & \\
\hline$\Sigma$ PCBs & $0,76^{*}$ & -0.48 & 0.57 & 0.19 & 0.64 & 0.57 & -0.24 & 1.00 & & \\
\hline$\Sigma$ PBDEs & 0.25 & -0.25 & -0.58 & -0.58 & -0.58 & -0.25 & -0.58 & -0.08 & 1.00 & \\
\hline$\delta^{15} N$ & -0.52 & -0.10 & -0.08 & -0.38 & 0.30 & 0.37 & 0.43 & -0.22 & -0.35 & 1.00 \\
\hline
\end{tabular}




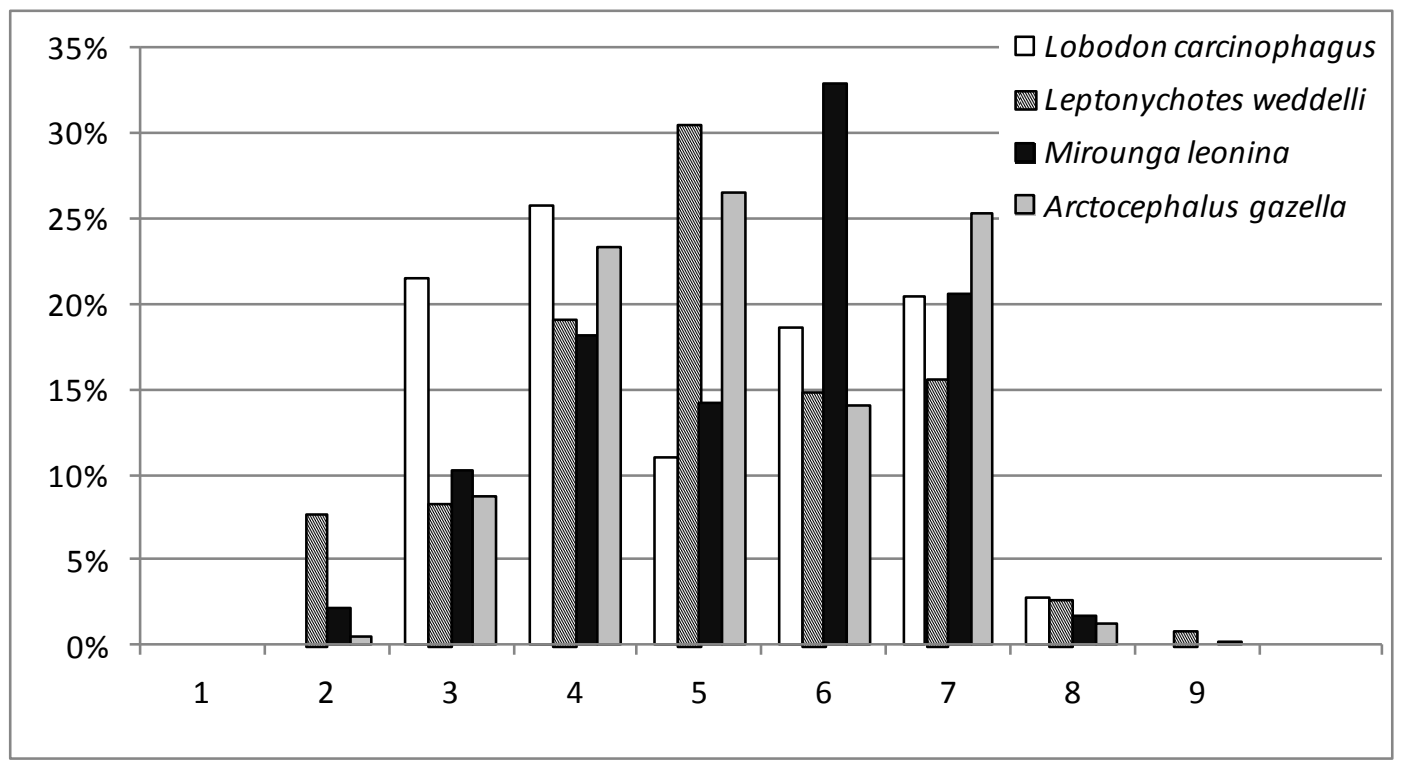

Figure 1 - PCBs distribution (\%) in fat from the Antarctic fur seal Arctocephalus gazella, the Weddel seal Leptonychotes weddelli, the crabeater seal Lobodon carcinophagus and in liver from the Southern Elephant seal Mirounga leonina from King George Island, according to chlorination number. 


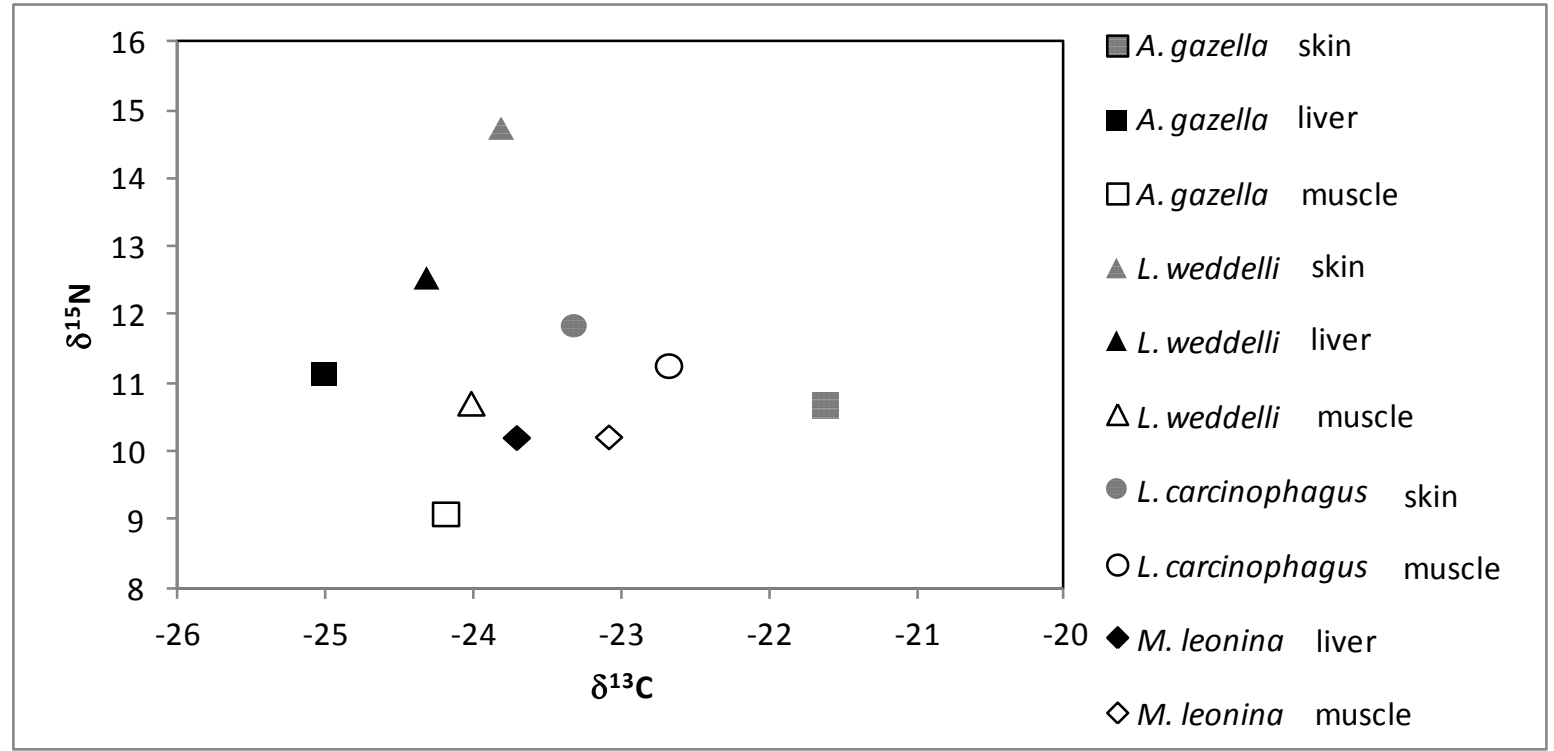

Figure 2 - Isotopic ratios (in \%o) in the tissues of the Antarctic fur seal Arctocephalus gazella, the Weddel seal Leptonychotes weddelli, the crabeater seal Lobodon carcinophagus, and the Southern Elephant seal Mirounga leonina from King George Island. 